\title{
5. 追跡調查一32
}

\section{精密検查の結果について}

\begin{tabular}{|c|c|c|c|c|}
\hline ○伊藤健次郎 & 野呂 & 光子 & 木内隆太郎 & 渡辺 \\
\hline 人倉 由美 & 今泉 & 満 & 吉川 治 & 白極 \\
\hline 國府田幸雄 & 藤崎 & 實 & 吉田 純一 & 松本 \\
\hline
\end{tabular}

東京医科大学病院総合健診センターと精検の結果につ いて開設後 1 年間の受診者の分析と, 精密検査の状況に ついて報告する。

昭和 61 年 4 月 1 日に竣工開院した東京医科大学病院 の 7 階に，医療情報管理センター（病院の host computor に附随しての）と並んで, 自動化健診システムを構 築し, 同時期に open した。

この総合健診センターは，病院組織の中では，あくま でも院内の診療部門の 1 つであり中央検査部, 球命球急 部等と同列であり, 近い将来, 講座として運営される予 定である。敢えて独立したセンター制をとらなかったの は, (1), 受診者の後処理 (精検・治療等) を効率よく 行うこと, (2), 職員人事の円滑化, (3), 中央検査科 の利用, (4), 職員 (医師を含めて) の総合健誩医学に 対する認識の向上 (教育), ( 5 ), ホストコンピュータ とのオンラインによる情報管理, そして現実の最大問題 として，(6), 開設後 15 年を経た東京実業総合健診セ ンターの受診者が増加して対応不全に陥入ったてと等々 である。従って病院全体の運用之深い関係があり, 総合 健診センターが独走出来ない恨みはあるが, 経営面では 病院全体の経理化にあり, 多少気が楽な点あある。

次に, このセンターの最初の 1 年間の受㡣者数は, 2,927 名で男性 1,693, 女性 1,234 名, 男女比 1.4 : 1.0, 平均年齢男女共 47.0 才, 更に, 764 名 (25.6\%) は要精検であった。即ち, 女性受㓌者が多く, 高龄者が 多く, 且つ異常を有する人が多いと言うことになる。乙 の病人が多いと言うことになる。この病人が多いと言う ことは，今後の対応を決定づける重要な課題であろう。 そして，乙の 764 名はそれぞれ院内各臨床科或は希望 の医師に紹介されましが，大半は障内への紹介である。 そこで, 判明している精検受診の結果について報告す

\section{The Results of Further Examination after} AMHTS

東京医科大学病院総合健診部
る。

\section{消化管精検例の内容について}

消化管レントゲン写真は, 消化器専門医による double check 制がとられ, 更に診察（面接）時に修正される が，下部消化管については，肚門直腸の視指診と，検便 所見ならびに問診と診察所見を総合して注腸透視を依頼 している。両者精検総数は, 紹介 335 名に対して, 72 名の未発診 $(21.5 \%)$ があり，263 名が内視鏡或は注腸 検査を受けた。

約 $14 \%$ の 52 名は, 異常なしとされ, 他はそれぞれ ほ病名下で治療或は経過観察が専門医のもとで行われて おり, 胃で最む多いのは, 胃炎 $(28.5 \%)$, 痽痕を含む 潰瘍 $(18.2 \%)$ ，ポリープ (13.6\%), 十二指腸潰瘍 $(6.0$ \%)などの順であり，胃癌は 2 例（全例対 $0.07 \%$ ）で あった。大腸では大腸癌（結腸）1例であった。

\section{掃人科検診結果について}

女性受診者 1234 名中, 770 名 $(61.5 \%)$ が婦人科を 受㡣しており， $80.3 \%$ が異常なし，7.3\% が支障なし， 要注意 $0.4 \%$, 要治療 $1.3 \%$, 引き続き要治療 $0.5 \%$, 要再検 $0.8 \%$, 要精検 $2.7 \%$ (22 名), 要観察 6.8\% の 割合である。

この 22 名, 要再検を含めて, 婦人科に紹介した 27 名 の実受診者であり，その精査の結果は筋腫 (40.9\%), びらん (27.2\%), 覀巣のう腫, ポリープ (夫々 $9.0 \%$ ), 癌 2 例であった。

又, 子宮細胞診腔クラスIII以上は 7 例である。

乳房は, 䛦察時の触診に由っているが, 10 名が外科 に紹介され, 乳癌 2 例であった。

其の他の各科に精査の目的を紹介された人について は，次の機会にゆずりたい。

以上, 新設の東京医科大学病院総合健診センターの報 告と共に, 消化管, 婦人科における精査の結果について 報告したが，更に受診者増加の時期に詳細を分析したい と思う。 